\title{
Keanekaragaman Megabentos yang Berasosiasi di Ekosistem Padang Lamun Perairan Wailiti, Maumere Kabupaten Sikka, Nusa Tenggara Timur
}

\author{
Ita Riniatsih dan Munasik \\ Departemen IImu Kelautan, Fakultas Perikanan dan IImu Kelautan, Universitas Diponegoro \\ JI. Prof. Soedarto, SH. Kampus UNDIP Tembalang, Semarang 50275 \\ Email : iriniatsih@yahoo.com
}

\begin{abstract}
Abstrak
Padang lamun di Perairan Wailiti yang berlokasi di pesisir Teluk Maumere Kabupaten Sikka, NTT, merupakan salah satu ekosistem laut dangkal yang mempunyai keanekaragaman hayati yang relative tinggi. Ekosistem padang lamun sebagai salah satu ekosistem pesisir di perairan tersebut mempunyai keanekaragaman biota laut yang hidup berasosiasi di dalamnya. Penelitian yang dilakukan dengan metode deskripsi lapangan ini menunjukan hasil pengamatan bahwa ditemukan sekitar empat jenis lamun, yaitu: Enhalus acoroides, Thalassia hemprichii, Cymodocea rotundata, dan Syringodium isoetifolium, tersebar di 3 stasiun pengamatan. Hasil analisa rata-rata \% penutupan lamun sebesar $47,085 \%$ dengan kategori kondisi lamun di Perairan Wailiti Kabupaten Sikka dalam kondisi kerapatan sedang. Biota laut yang berasosiasi di padang lamun yang terlihat di lokasi pengamatan antara lain adalah bulu babi, teripang keling, teripang sabuk raja, bivalvia kima, gastropoda dan ular laut.
\end{abstract}

Kata Kunci : Lamun, tutupan, Thalassia hemprichii, sebaran

\section{PENDAHULUAN}

Ekosistem padang lamun salah satu ekosistem di wilayah pesisir yang mempunyai produktivitas primer yang relative tinggi dan mempunyai peranan yang penting untuk menjaga kelestarian dan keanekaragaman orgnisme laut. Adi (2000) ; Chute et al. (2001) dan Helfman et al. (2009) menjelaskan padang lamun sebagai salah satu ekosistem laut dangkal di daerah pesisir banyak mempunyai fungsi ekologis yang sangat penting sebagai daerah pemijahan dan asuhan bagi berbagai jenis oegnisme laut. Padang lamun mempunyai peranan penting dalam menjaga keseimbangan ekosistem di perairan laut. Salah satu fungsi fisik padang lamun adalah sebagai pendaur ulang zat hara di perairan. Aktivitas mikroorganisme pengurai mengembalikan bahan anorganik ke perairan melalui proses dekomposisi dari bahan organik atau jaringan hidup yang berupa detritus serasah lamun. Bahan anorganik sebagai nutrien atau zat hara ini sangat dibutuhkan oleh lamun.
Alcala (1991) dalam Riniatsih (2007) bahwa perairan bervegetasi lamun mempunyai keanekaragaman dan kelimpahan organisme yang berasosiasi yang lebih tinggi jumlahnya, apabila dibandingkan dengan perairan yang tidak bervegetasi lamun. Untuk itu pengelolaan ekosistem padang lamun sangat diperlukan untuk menjaga produktivitas sumbedaya perikanan dan kelestarian kekayaan alam di daerah pesisir. Keterkaitan antara kondisi padang lamun dengan kondisi ekosistem pesisir lainnya yang meliputi ekosistem terumbu karang dan hutan mangrove sangat berpengaruh terhadap keseimbangan dan kelestarian sumberdaya alam di wilayah pesisir (Tomaschick et al., 1997). Untuk itu, ekosistem padang lamun perlu dijaga kelestariannya karena mempunyai peranan penting dalam menjaga keseimbangan ekosistem di perairan laut.

Ekosistem padang lamun pada umummnya merupakan habitat bagi berbagai jenis organisme laut yang hidup 
berasosiasi di dalamnya. Organisme bentik sebagai organieme penyerta yang hidup sebagai orgsanisme di dasar perairan mempunyai fungsi tersendiri dalam suatu ekosistem perairan. Kondisi kesehatan padang lamun akan dapat mempengaurhi keberadaan organisme bentik tersebut. Mengingat fungsi ekologis yang cukup penting dan pengamatan bagi organisme megabentos di padang lamun serta studi keberadaannya masih belum banyak, maka kajian ini masih sangat perlu dilakukan.

\section{MATERI DAN METODE}

Metode pengamatan untuk kondisi lamun yang digunakan pada penelitian ini adalah dengan metoda transek kuadrant (garis transek secara tegak lurus garis pantai ke arah laut) yang dimodifikasi dari metode Seagrass Watch (Rachmawati et al., 2014). Transek kuadran ukuran 0,5 × 0,5 $\mathrm{m}$ diletakkan di setiap 10 meter untuk pengamatan lamun. Pengamatan pada tiga sub stasiun pengamatan yang sudah ditentukan secara purposif sesuai dengan tempat terdapatnya komunitas lamun dan makroalgae. Untuk pendataan organisme megabentos yang berasosiasi di padang lamun dilakukan dengan menggunakan metoda Benthos Belt Transeck (BBT) yang merupakan Modifikasi dari metoda Belt Transeck (Munro, 2013 dalam Suharsono dan Sumadhiharga, 2014).

\section{HASIL DAN PEMBAHASAN}

Hasil pengamatan tentang ekosistem padang lamun di Wailiti Teluk Maumere, Kabupaten Sikka, bahwa di lokasi pengamatan terdapat empat jenis lamun yang ditemukan menyebar di tiga lokasi pengamatan, yaitu Enhalus

Tabel 1. Komposisi Jenis Lamun di Setiap Sub Stasiun perairan Wailiti

\begin{tabular}{llll}
\hline \multirow{2}{*}{\multicolumn{1}{c}{ Jenis Lamun }} & \multicolumn{3}{c}{ Stasiun } \\
\cline { 2 - 4 } \multicolumn{1}{c}{} & 1 & 2 & 3 \\
\hline Enhalus acoroides & + & + & + \\
Thalassia hemprichii & + & + & + \\
Cymodocea rotundata & + & + & + \\
Syringodium isoetifolium & + & + & - \\
\hline
\end{tabular}

acoroides, Thalassia hemprichii, Cymodocea rotundata, dan Syringodium isoetifolium. Lamun jenis Enhalus acoroides dan Thalassia hemprichii ditemukan di semua sub stasiun pengamatan, demikian juga jenis Cymodocea rotundata, terlihat di semua stasiun pengamatan.

Hasil pengamatan memperlihatkan bahwa di lokasi stasiun 1 dan 2 di perairan Wailiti ditemukan 4 spesies lamun. Lokasi ini merupakan lokasi yang terbanyak ditemukan spesies lamun dibandingkan dengan stasiun lainnya. Stasiun 3 merupakan stasiun dengan jenis lamun yang relative lebih sedikit dibandingkan dengan stasiun lainnya. Hal ini diduga karena stasiun 3 merupakan stasiun yang paling berdekatan dengan pemukiman penduduk, dan merupakan lokasi penambatan perahu nelayan. Aktivitas lalu liantas perahu nelayan dan aktifitas masyarakat nelayan yang sering memanfaatkan padang lamun sebagai tempat mencari ikan diduga dapat mempengaruhi kondisi padang lamun di lokasi tersebut. Hal ini sesuai dengan pendapat Tomascick et al. (1997) bahwa tekanan yang sering dialami oleh ekosistem padang lamun adalah adanya aktifitas masyarakat pesisir yang banyak menfaatkan padang lamun sebagai tempat menangkap ikan dan sebagai jalur lalu lintas kapal nelayan. Hasil perhitungan Penutupan lamun Tabel 2.

Kondisi \% penutupan lamun di perairan pesisir Kabupaten Sika secara umum memperlihatkan kondisi yang baik dengan rata-rata sebesar $47,08 \%$ dengan kisaran antara $19,37-60,3 \%$. Tabel 2 di atas menunjukkan bahwa sebaran jenis lamun dan \% penutupan sangat beragam. Ratarata \% penutupan lamun di lokasi pengamatan termasuk dalam kategori kondisi sedang, dengan penutupan masuk dalam kelompok antara 26-50. Hal ini menunjukkan bahwa kondisi padang lamun di lokasi tersebut masih relative baik. Kondisi perairan yang terlindung dengan kecerahan hingga dasar perairan di lokasi pengamatan merupakan kondisi yang sangat baik bagi pertumbuhan lamun. Biota laut yang berasosiasi di ekosistem selama pengamatan menunjukkan keragaman yang relative 
tinggi. Makroalga banyak ditemukan hidup berasosiasi di ekosistem padang lamun, terutama pada stasiun 2 dan 3. Makroalga yang ditemukan selama pengamatan di lokasi penelitian antara lain adalah jenis Caulerpa sp., Padina sp., Halimeda sp., Turbinaria sp, Ampiroa sp. dan Dyctyota sp. Makroalga atau rumput laut merupaka vegetasi yang sering ditemukan hidup berasosiasi dengan lamun di suatu perairan. Keanekaragaman makroalga di padang lamun turut memberikan sumbangan nutrient perairan dan ketersediaan tempat berlindung atau habitat bagi oganisme laut lainnya yang hidup berasosiasi di padang lamun (Kadi, 2009).

Tabel 2. Hasil Perhitungan \% Penutupan Lamun di setiap Stasiun di Pesisir Wailiti di Maumere Kabupaten Sikka (\%)

\begin{tabular}{lccc}
\hline \multirow{2}{*}{\multicolumn{1}{c}{ Jenis Lamun }} & \multicolumn{3}{c}{ Stasiun } \\
\cline { 2 - 4 } & 1 & 2 & 3 \\
\hline Enhalus acoroides & 29,37 & 34,58 & 19,37 \\
Thalassia hemprichii & 60,3 & 49,7 & 58,7 \\
$\begin{array}{l}\text { Cymodocea } \\
\text { rotundata }\end{array}$ & 56,7 & 58,7 & 55,5 \\
$\begin{array}{l}\text { Syringodium } \\
\text { isoetifolium }\end{array}$ & 38,7 & 34,6 & 0 \\
\hline
\end{tabular}

Tabel 3. Hasil Kelimpahan Megabentos di setiap Stasiun di Pesisir Wailiti di Maumere Kabupaten Sikka (Ind/m²)

\begin{tabular}{lccc}
\hline \multirow{2}{*}{\multicolumn{1}{c}{ Jenis Lamun }} & \multicolumn{3}{c}{ Stasiun } \\
\cline { 2 - 4 } & 1 & 2 & 3 \\
\hline Holothutia atra & 0,04 & 0,03 & 0,02 \\
Synapta maculata & 0,03 & 0,04 & 0,03 \\
Tridacna sp. & 0,007 & 0 & 0 \\
Anadara sp. & 0,01 & 0 & 0,01 \\
Trochus sp. & 0,04 & 0,09 & 0,04 \\
Diadema sp. & 0,07 & 0,09 & 0,07 \\
Pinctada sp. & 0 & 0 & 0,01 \\
Tunicata & 0,03 & 0,03 & 0 \\
\hline
\end{tabular}

Organisme megabentos yang paling banyak ditemukan selama penelitian adalah gastropoda (Trochus sp.) dan bulu babi, khususnya di stasiun 2. Stasiun 2 merupakan lokasi dengan kerapatan lamun yang relative paling tinggi dibandingkan stasiun pengamatan lainnya. Hal ini diduga karena kondisi lamun yang rapat biasanya merupakan habitat yang paling baik untuk berlindung bagi berbagai jenis organisme laut (Riniatsih dan Widianingsih, 2007; Pratiwi, 2010). Sebagian besar organism laut memanfaatkan padang lamun sebagai tempan untuk berlindung dan mencari makan, terutama organism bentik yang banyak memanfaatkan detritus serasah lamun sebagai bahan organik dan bakteri sebagai sumber makanananya.

Selama pengamatan sering ditemukan berbagai jenis ikan hias maupun juvenile ikan yang memanfaatkan padang lamun sebagai tempat untukberlindung danmencari makan. Juvenil ikan beronang (Siganus sp.) banyak ditemukan sedang memakan perifiton yang banyak tumbuh di permukaan daun lamun jenis Enhalus acoroides. Selain itu juvenile dari ikan karang dan ikan Chaetodontidae banyak ditemukan berlindung dan memanfaatkan beberapa koloni karang berabang (Acropora sp.) untuk tempat hidupnya. Beberapa koloni karang bercabang banyak tumbuh berasosiasi di padang lamun di stasiun 1 dan 2 di lokasi pengamatan. Megabentos yang sering ditemukan adalah bulu babi, teripang (Holothuria sp), teripang sabuk raja, bivalvia (Anadara sp), tiram mutiara, kima, gastropoda (Conus sp.), dan ular laut. Untuk beberapa stasiun, lamun terlihat hidup berasosiasi dengan terumbu karang bercabang (Acropora sp.), karang massif, sub massif dan karang fungia.

\section{KESIMPULAN}

Kondisi padang lamun di perairan Wailiti, Kabupaten Sikka dengan rata-rata \% penutupan sebesar $47,085 \%$ termasuk dalam kategori kondisi kerapatan sedang. Biota laut yang berasosiasi di padang lamun yang ditemukan di lokasi penelitian antara lain adalah: bulu babi, teripang keling, teripang sabuk raja, bivalvia kima, gastropoda dan ular laut. 
DAFTAR PUSTAKA

Adi, W. 2007. Komposisi dan Kelimpahan Larva dan Juvenil Ikan yang Berasosiasi dengan Tingkat Kerapatan Lamun yang Berbeda di Pulau Panjang Jepara. Jurnal Sumberdaya Perairan. Vol 1. Edisi 1.

Dahuri, R. 2003. Keanekaragaman Hayati Laut. Penerbit PT. Gramedia Pustaka Utama, Jakarta XXXIII + $412 \mathrm{hlm}$.

Fortes, M.D. 1990. Seagrasses: A Resources Unknown in The Asean Region. Iclarm Education Series 5. International Center for Living Aquatic. Resources Management Manila, Philippines.

Helfman, G.S., B.B. Collete, D.E. Facey dan B.W. Bowen 2009. Diversity of Fishes: Biology, Evoluation and Ecology. 2nd. Eds. Wiley-Blacwell: John Wiley and Sons Ltd. Chichester. UK.737 pp.

Kadi, Achnad. 2009. Rumput Laut Jenis Lokal dan Jenis Pendatang di Paparan Terumbu Karang Pulau Pari Jakarta Utara. Jurnal IImu Kelautan. Vol. 14 (1): 1-5

Moriniere, E,C., B.J.A. Phollux, I. Nagelkerken, \& G.V. Velde. 2000. PostSettelment Life Cycle Migration Patterns and Habitat Preference of Coral Reef Fish that Use Seagrass and Mangrove Habitat as Nurseries.
Estuarine Coastal and Shelf Science (2002) 55:309-321.

Pratiwi, R., 2010. Asosiasi Kristacea di Ekosistem Padang lamun Perairan Teluk Lampung. Jurnal Ilmu Kelautan. Vol 15(2):59-65.

Rachmawati, S., Andi I., Indarto H.S., \& Muhmmad H.A. 2014. panduan Monitoring Padang Lamun. (Editor: Malik Kusworo H.\& Anugerah N.). COREMAP CTI, Pusat Penelitian Oseanografi. LIPI-Indonesia.

Riniatsih, I., dan Widianingsih. 2007. Kelimpahan dan Pola sebaran Kerang-kerangan (Bivalvia) di Ekosistem Padang Lamun Perairan Jepara. Jurnal Ilmu Kelautan. Vol 12(1)

Suharsono \& Ono K.S. 2014. Panduan Monitoring Kesehatan terumbu Karang; Terumbu Karang, Ikan Karang, Megabentos dan Penulisan Laporan. Coremap CTI. Lembaga IImU Pengetahuan Indonesia.

Sulaeman, 2005. Analisa Kimia Tanah, Tanaman, Air dan Pupuk. Balai Penelitian Tanah dan Pengembangan Pertanian, Departemen Pertanian, Bogor.

Tomascick, T., A.J. Mah, A. Nontji \& M.K. Kasim Moosa. 1997. The Ecology of the Indonesia Seas. Part One. Periplus Edition (HK) Ltd., Singapore. 